\title{
The effect of diazepam on the EEG of status epilepticus
}

\author{
D. S. BELL \\ From the Psychiatric Research Unit, Callan Park Hospital, Rozelle, N.S.W. 2039, Australia
}

The electroencephalogram has been used infrequently for monitoring the treatment of status epilepticus. In fact, the EEG of status epilepticus has received little attention and its features are comparatively unknown. Many factors have contributed to this neglect. Because status epilepticus is a medical emergency, the urgent need to institute treatment may not allow the time to transport the convulsing and perhaps hypoxic patient to the laboratory, much less the time to obtain the EEG. Undoubtedly the anticipation of insuperable technical problems in obtaining a useful record has deterred some.

A partial exception to this general picture of neglect is the documentation of the effects of diazepam. Gastaut, Naquet, Poiré, and Tassinari (1965); Gastaut, Roger, Soulayrol, Lob, and Tassinari (1965); Piqué and Henking (1965); Revol, Courjon, Gerin, and Fischer (1965); Bamberger and Matthes (1966); Lombroso (1966); Jaffe and Christoff (1967); Prensky, Raff, Moore, and Schwab (1967); Bell (1969); and Nicol, Tutton, and Smith (1969) used the EEG to monitor the effects of intravenously administered diazepam. However, as each of these reports was practically confined to the clinical effects of diazepam, the EEG of status epilepticus and its modification by diazepam remain incompletely documented.

Bell and Kiloh (1970) have described the EEG characteristics of convulsive status. Brief paroxysmal discharges showing the characteristics of the 'afterdischarge' appeared during the interictal and ictal periods. The seizure discharge also commonly had the form of the 'after-discharge', the first two stages of which, asynchronous activity and recruitment, preceded the convulsion. The authors pointed out that the term 'after-discharge' implies a time relationship to the clinical event that is misleading and suggested that it be renamed the 'recruiting discharge'. They also described an interictal larval seizure discharge resembling the sleep spindle, which they named the 'spindle discharge'. The spindle discharge is probably the rhythmic synchronous stage of a brief bilateral recruiting discharge.

An alpha-like activity similar to the rhythmic discharge which accompanied the majority of convulsions appeared in some cases of status epilepticus during the interictal period. Bell and Kiloh (1970) suggested that both the ictal and interictal activity be named the 'rhythmic seizure discharge'.

In the following description of the changes seen in the EEG of status epilepticus after the intravenous administration of diazepam, this paper will use the suggested terminology.

\section{CASE MATERIAL}

From 1966 to 1969,17 patients had EEG recordings during convulsive status treated with intravenous diazepam. In each case the status consisted of attacks of convulsive activity between which the patient failed to recover consciousness fully. As all the patients were transferred from psychiatric hospitals and included cases refractory to conventional treatment methods available in the wards, the group is highly selected and representative of the more intractable and severe forms of status epilepticus.

Details of the patients, their epilepsy, the episodes of status epilepticus, and the treatment are summarized in the Table. The status was arrested promptly after treatment with intravenous diazepam in seven cases $(1,4,5,6,8,13$, and 15$)$, although in three $(1,5$, and 13) sporadic seizures continued for a few hours after. In six cases $(9,10,11,12,14$, and 16) the first dose of diazepam temporarily arrested the seizures and subsequent doses had a similar effect until the status ceased. Although the first dose of diazepam temporarily arrested the status epilepticus in two other cases, paraldehyde proved to be more effective in arresting the alcoholwithdrawal seizures of one patient (case 7) and intravenous phenytoin the phenytoin-withdrawal seizures of the other (case 17).

The convulsions in case 3 responded temporarily to diazepam, each dose of which was successively less effective; the patient failed to gain lasting benefit from other drugs or anaesthesia and eventually died after 13 days of status epilepticus. Serious hypotension followed treatment with diazepam in cases 9 and 16, in the latter instance leading to death. One other patient (case 10) died within four weeks of treatment, apparently as a consequence of the underlying disorder rather than of the status epilepticus. 
DETAILS OF THE CASES

\begin{tabular}{|c|c|c|c|c|c|c|c|c|c|}
\hline \multirow[t]{2}{*}{ Case } & \multirow[t]{2}{*}{ Sex } & \multirow[t]{2}{*}{ Age } & \multicolumn{2}{|c|}{ Seizure Localization } & \multicolumn{2}{|c|}{ Details of status } & \multirow{2}{*}{$\begin{array}{l}\text { Other drugs } \\
\text { (parenteral) }\end{array}$} & \multicolumn{2}{|c|}{ Diazepam treatment } \\
\hline & & & Convulsion & $E E G$ & Duration & $\begin{array}{l}\text { Level of } \\
\text { consciousness }\end{array}$ & & $\begin{array}{c}\text { Total } \\
(m g)\end{array}$ & Response \\
\hline 1 & $\mathbf{M}$ & 23 & $\begin{array}{l}\text { Right side, } \\
\text { secondarily } \\
\text { generalized }\end{array}$ & $\begin{array}{l}\text { Left } \\
\text { anterior } \\
\text { temporal }\end{array}$ & 3 days & Clouded & $\begin{array}{l}\text { paraldehyde } \\
\text { phenobarb } \\
\text { phenytoin }\end{array}$ & 40 & Lasting \\
\hline 2 & $\mathbf{M}$ & 66 & $\begin{array}{l}\text { Generalized } \\
\text { (myoclonus) }\end{array}$ & Generalized & 1 day & Clouded & paraldehyde & 10 & Poor \\
\hline 3 & $\mathbf{M}$ & 23 & $\begin{array}{l}\text { Right side, } \\
\text { secondarily } \\
\text { generalized }\end{array}$ & $\begin{array}{l}\text { Left } \\
\text { mid-temporal }\end{array}$ & 13 days & Coma & $\begin{array}{l}\text { paraldehyde } \\
\text { phenytoin } \\
\text { thiopentone }\end{array}$ & 310 & $\begin{array}{l}\text { Temporary, } \\
\text { decreasing to } \\
\text { succeeding doses }\end{array}$ \\
\hline 4 & $\mathbf{M}$ & 29 & Generalized & Left frontal & 3 hours & Clouded & - & 20 & Lasting \\
\hline 5 & $\mathbf{F}$ & 59 & $\begin{array}{l}\text { Right side, tonic } \\
\text { generalized }\end{array}$ & Generalized & 4 hours & Coma & - & 40 & Lasting \\
\hline 6 & $\mathbf{M}$ & 20 & $\begin{array}{l}\text { Myoclonus, } \\
\text { generalized }\end{array}$ & Generalized & 4 hours & Stupor & - & 10 & Lasting \\
\hline 7 & $\mathbf{M}$ & 48 & Right side & $\begin{array}{l}\text { Left } \\
\text { mid-temporal }\end{array}$ & 2 days & Coma & $\begin{array}{l}\text { paraldehyde } \\
\text { phenytoin }\end{array}$ & 40 & Temporary \\
\hline 8 & $\mathbf{F}$ & 30 & $\begin{array}{l}\text { Right arm } \\
\text { and face }\end{array}$ & $\begin{array}{l}\text { Left hemi- } \\
\text { sphere }\end{array}$ & $1 \frac{1}{2}$ hours & Coma & - & 20 & Lasting \\
\hline 9 & $\mathbf{F}$ & 69 & $\begin{array}{l}\text { Right side, } \\
\text { secondarily } \\
\text { generalized }\end{array}$ & Left frontal & 10 days & Stupor & $\begin{array}{l}\text { paraldehyde } \\
\text { phenobarb }\end{array}$ & 320 & Temporary \\
\hline 10 & $\mathbf{F}$ & 60 & Right side & $\begin{array}{l}\text { Left anterior } \\
\text { temporal }\end{array}$ & $2 \frac{1}{2}$ days & Stupor & phenobarb & 260 & Temporary \\
\hline 11 & $\mathbf{F}$ & 31 & $\begin{array}{l}\text { Right side, } \\
\text { secondarily } \\
\text { generalized }\end{array}$ & Generalized & 2 days & Stupor & $\begin{array}{l}\text { paraldehyde } \\
\text { phenobarb } \\
\text { phenytoin }\end{array}$ & 160 & Temporary \\
\hline 12 & $\mathbf{F}$ & 15 & Generalized & Generalized & 3 days & Clouded & - & 160 & Temporary \\
\hline 13 & $\mathbf{M}$ & 22 & $\begin{array}{l}\text { Right side, } \\
\text { secondarily } \\
\text { generalized }\end{array}$ & $\begin{array}{l}\text { Left } \\
\text { mid-temporal }\end{array}$ & $4 \frac{1}{2}$ hours & Stupor & $\begin{array}{l}\text { paraldehyde } \\
\text { phenobarb } \\
\text { phenytoin }\end{array}$ & 60 & Lasting \\
\hline 14 & $\mathbf{M}$ & 41 & $\begin{array}{l}\text { Right side, } \\
\text { secondarily } \\
\text { generalized }\end{array}$ & $\begin{array}{l}\text { Left } \\
\text { frontal }\end{array}$ & 28 hours & Stupor & phenobarb & 100 & Temporary \\
\hline 15 & $\mathbf{M}$ & 13 & Generalized & Generalized & 8 hours & Clouded & - & 10 & Lasting \\
\hline 16 & $\mathbf{F}$ & 37 & Generalized & Generalized & $1 \frac{1}{2}$ days & Coma & $\begin{array}{l}\text { paraldehyde } \\
\text { phenobarb } \\
\text { phenytoin }\end{array}$ & 810 & Temporary \\
\hline 17 & $\mathbf{M}$ & 38 & Generalized & $\begin{array}{l}\text { Right } \\
\text { hemisphere }\end{array}$ & $3 \frac{1}{2}$ hours & Coma & $\begin{array}{l}\text { phenobarb } \\
\text { phenytoin }\end{array}$ & 60 & Temporary \\
\hline
\end{tabular}

The recordings were made with an Offner T.C. 16channel EEG machine. In most cases, saline pad silver/ silver-chloride electrodes were used and in the rest collodion affixed silver/silver-chloride electrodes. The first dose of diazepam, usually $5 \mathrm{mg}$ given slowly intravenously, provided the guide for the subsequent rate of administration. Although an initial amount of $10 \mathrm{mg}$ usually arrested the seizures, in most cases further doses were needed to terminate the status.
In seven cases $(4,5,6,8,12,13$, and 15) an EEG was obtained before parenteral drug treatment was instituted and in a further three $(1,9$, and 16$)$ before diazepam was given. In the latter 10 cases and in four more $(3$, 7,14 , and 17) the effects of an intravenous dose of $\sigma$ diazepam were monitored. In cases 2,10 , and 11 the $N$ intravenous diazepam had been given before the recording was commenced. 


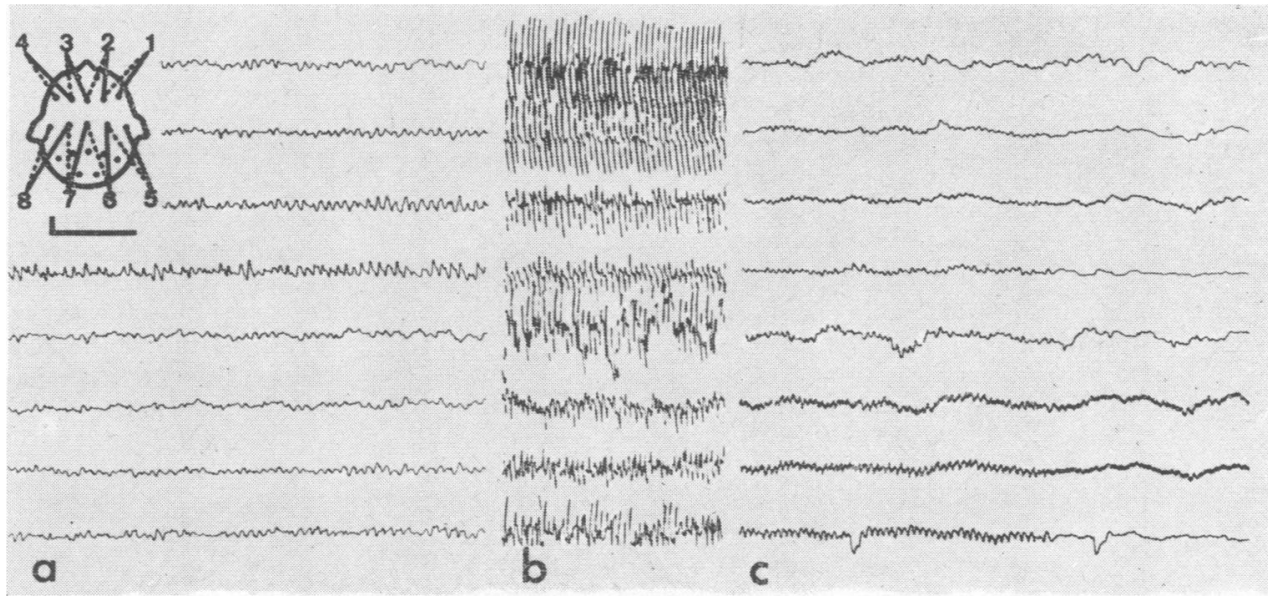

FIG. 1. Case 9. (a) Onset of pre-convulsive focal rhythmic seizure discharge. (b) Tonic stage of secondarily generalized convulsion during which administration of diazepam was commenced. (c) End of rhythmic seizure discharge which, after diazepam was given, gradually diminished in amplitude and extent in parallel to a similar regression of the convulsion. Calibrations for all figures: $1 \mathrm{sec}, 50 \mu \mathrm{V}$.

\section{OBSERVATIONS}

Clinical and EEG signs of the effects were apparent within 20 seconds of the start of the intravenous injection of diazepam. A progressive decrease in amplitude of the epileptiform activity was accompanied by a reduction or disappearance of convulsive movements. Generalized fast activity appeared within two minutes. In case 4 the generalized delta increased in amplitude for a few minutes.

In three cases $(1,9$, and 10$)$ of focal motor seizures that progressed to generalized convulsions, diazepam given during the generalized seizure reversed the course of the convulsions. As the movements became restricted to the limb in which the focal convulsion had commenced, the EEG also changed from a generalized to a lateralized discharge (Fig. 1). In four cases $(3,9,10$, and 14) the convulsions were clinically and electrographically more localized when they resumed after a temporary arrest due to treatment.

In five cases $(8,9,12,15$, and 17) the seizure discharges were reduced in amplitude but continued to recur, despite the arrest of the convulsions, at the same rate and with the same duration as before the administration of diazepam (Figs. 2 and 3). The persistence of the discharges did not necessarily indicate that the convulsions would recur-in two

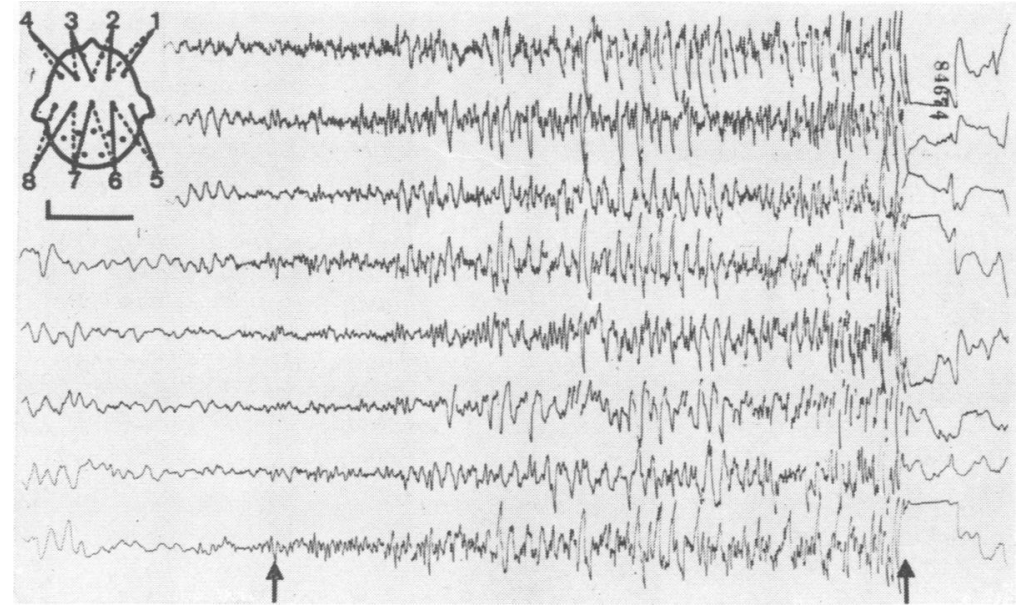

FIG. 2. Case 12. Seizure discharge before treatment with diazepam. Arrows indicate onset and end of tonic convulsion. 


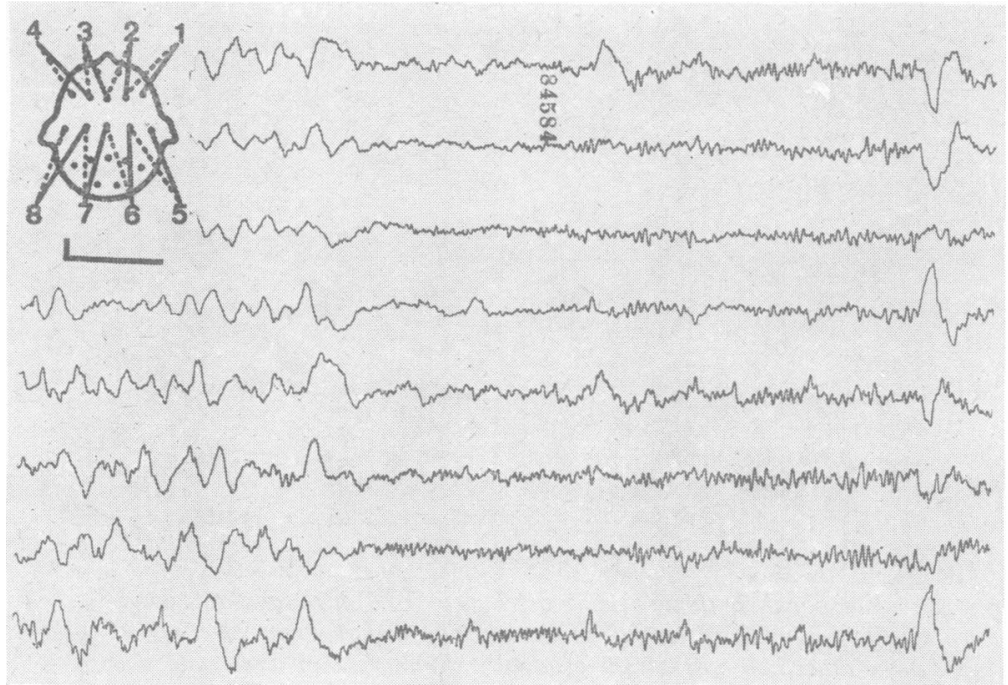

FIG. 3. Case 12. After administration of diazepam had arrested the convulsions, subclinical seizure discharges such as these continued to recur at the same rate and with the same duration as the convulsive discharges before treatment (Fig. 2).

of the cases (8 and 15) the status ceased altogether after the single dose of diazepam.

Subclinical seizure discharges appeared in six cases $(1,3,7,9,16$, and 17$)$ at a stage when the convulsions had been reduced in severity or duration, starting many seconds or even minutes before the convulsion and continuing after the movements had ceased. Comparison with the pre-treatment EEG was not possible in these cases-some parenteral anticonvulsant treatment had been given before the recording was commenced-but further administration of diazepam increased the subclinical proportion of the seizure discharge. In one case (4) however, a recording of the epileptic status before treatment was initiated showed a rhythmic seizure discharge which lasted 90 seconds before and more than 30 seconds after the convulsion.

In two cases ( 3 and 7$)$ the rhythmic seizure $\stackrel{\mathbb{1}}{\varrho}$ 을 discharge did not cease in the interictal period $\rightarrow$ (Fig. 4), although it did show a gradual reduction in amplitude after a convulsion and an increase before the next. When this stage was reached in case 3 , the status proved intractable to treatment. In case 7 the continuous discharge ceased after the patient was given paraldehyde.

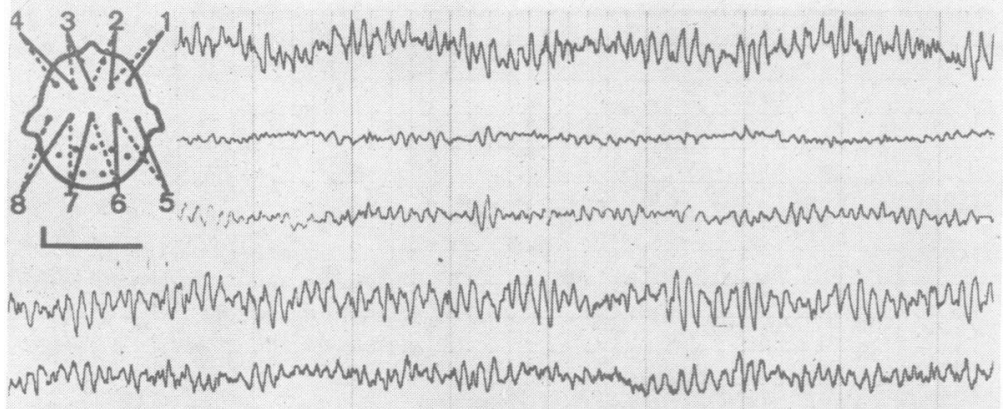

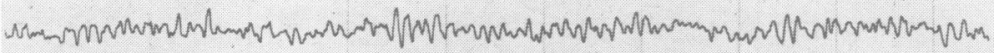

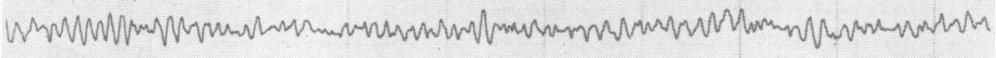

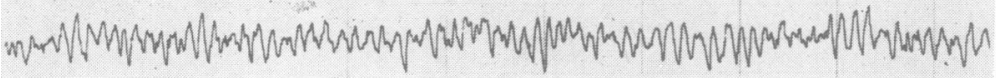

FIG. 4. Case 3. Continuous interictal alpha-like rhythmic seizure discharge on seventh day of status epilepticus intractable to treatment with diazepam or other drugs. The discharge was not reactive to stimuli, the patient was comatose and before each convulsion the discharge increased in amplitude and was continuous with and indistinguishable from the convulsive discharge. 


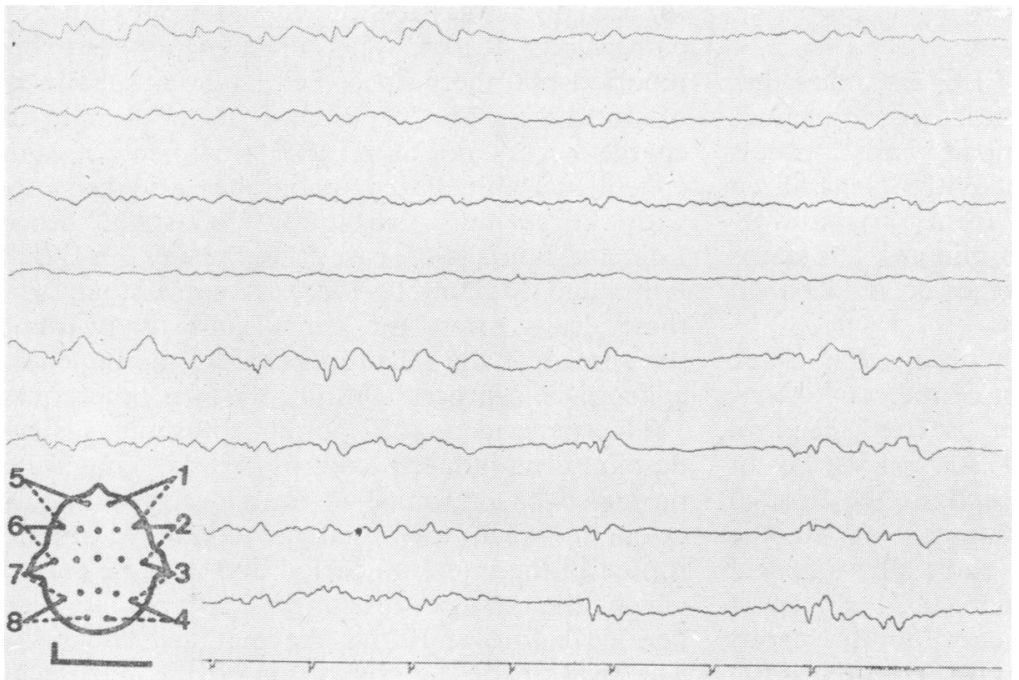

FIG. 5. Case 8. Burst suppression recorded 1 min after intravenous administration of $20 \mathrm{mg}$ diazepam had arrested the convulsions.

The spindle discharges and brief recruiting discharges in some cases were recorded many hours after the convulsions were arrested.

BURST SUPPRESSION Burst suppression was recorded from three patients $(8,9$, and 16$)$ during the period of drug-induced arrest of the convulsions (Figs. 5 and 6). The bilaterally synchronous periods of electrical silence each began with a delta wave, usually lasted one to three seconds and appeared 30 to 65 seconds after the intravenous administration commenced. As the effect of the drug began to wane, the burst suppression recurred less frequently and became shorter in duration.
The burst suppression appeared to interact with epileptiform activity in two cases. In case 8 each subclinical seizure discharge was preceded by a burst suppression that lasted longer than usualup to 10 seconds. Further administration of diazepam reduced the amplitude of the discharge and the duration of the preceding electrical silence. In case 16 , during the temporary arrest of the convulsions, each brief recruiting discharge was followed by a burst suppression.

Burst suppression was asymmetrical in one patient (case 9) who also had unilateral attenuation. On the side of the attenuation the slow wave of onset was reduced in amplitude and the duration of electrical silence was longer (Fig. 6).
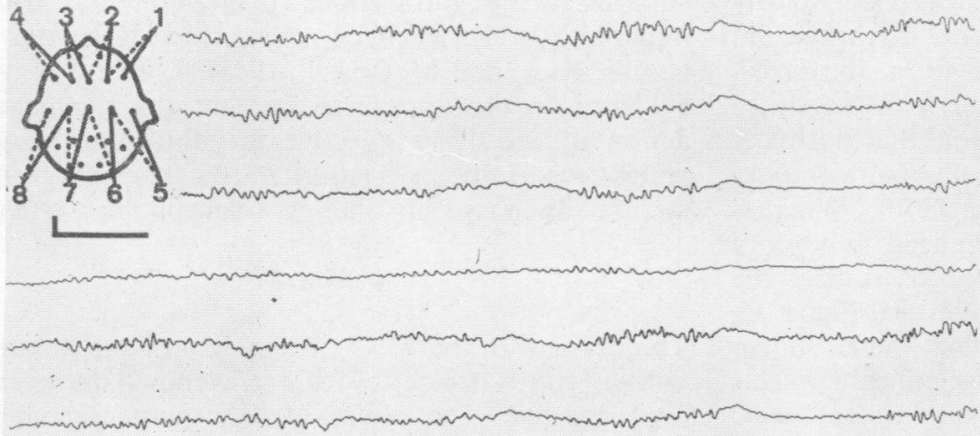

FIG. 6. Case 9. Burst suppression accompanying left hemisphere attenuation. On the left side the slow wave at the onset of each burst is attenuated and the duration of electrical silence is longer. 


\section{DISCUSSION}

The effect of diazepam on the EEG resembles that of the rapidly acting barbiturates. An intravenous dose sufficiently large to impair consciousness results in generalized delta activity. Generalized fast waves indistinguishable from 'barbituratefast' activity appear within two minutes. In status epilepticus the seizure discharge is reduced in amplitude or ceases altogether.

The burst suppression which occurred in three of our patients during the arrest of the convulsions has also been recorded from isolated cerebral cortex (Henry and Scoville, 1952), in a variety of disorders (Delamonica, 1968), and in the normal neonate. The common denominator of all the states in which it occurs appears to be "physiological isolation' of the cortex (Delamonica, 1968). Burst suppression is a well-recognized effect of intravenous thiopentone (Fenton, Hill, and Scotton, 1968) and has been reported to occur in barbiturate coma (Ellington, 1968). Burst suppression following treatment of status epilepticus with parenteral barbiturates appears to have-occurred in case 7 of Gastaut, Poiré, Roger, and Lob (1967) and case 8 of Gastaut, Roger, Lob, and Poiré (1967). It does not seem to have been reported previously as an effect of intravenous diazepam, although it is in fact illustrated in Fig. 3c of Nicol et al. (1969). The fact that the burst suppression was bilaterally synchronous and generalized in all these cases suggests that the 'physiological isolation' of the cortex had been effected at the level of central subcortical structures.

Piqué and Henking (1965) observed that, after diazepam is given, secondarily generalized seizure discharges are reduced or cease and are replaced by the focal discharge. In three of our cases in which diazepam was administered during secondarily generalized convulsions, the seizure discharge did not end as usual, but reverted to a focal discharge before ceasing altogether. This sequence differs from the process of 'extinction' that normally terminates the seizure and arrests all seizure activity simultaneously (Bell and Kiloh, 1970). Whereas 'extinction' is probably a generalized inhibitory discharge, diazepam would appear to restrict the spread of seizure activity. Guerrero-Figueroa, Rye, and Guerrero-Figueroa (1968) have shown that diazepam in the cat has insignificant effects on epileptiform activity in primary epileptogenic tissue, but prevents the development of secondary epileptiform discharges. Barbiturates have a similar action (Morrell, 1960).

Gastaut, Naquet, Poiré, and Tassinari (1965) observed that in some cases of focal epilepsy the seizure discharges continued to recur after the convulsions ceased. This phenomenon has been reported by others since then and was seen in five of our cases. The persistence of the seizure discharge occurs not only after treatment of status epilepticus with diazepam but has also been seen with intravenous barbiturate (Gastaut, Roger, Lob, and Poiré, 1967, case 1) and phenytoin (Wallis, Kutt, and McDowell, 1968). It seems that, while these drugs arrest the convulsions by restricting the spread of the seizure discharge, the underlying epileptogenic process follows its own time course.

The persistence of the epileptogenic disorder despite drug-induced control of the convulsions may also be presumed to have occurred in those cases in which the discharge continued uninterrupted in the interictal period and in those cases in which the seizure discharge appeared for long periods before and after the modified convulsion. The relation of the convulsion to the seizure discharge may be likened in these cases to the visible part of an iceberg. This 'iceberg phenomenon' was seen in one case before diazepam was given, but in other cases treatment appeared to accentuate the phenomenon. Furthermore, the considerable epileptiform activity seen during status epilepticus disappeared slowly, lasting many hours and sometimes many days after the convulsions were arrested.

The appearance of burst suppression and the persistence of the cortical seizure discharge in the absence of convulsive movements suggest a druginduced impairment of cortical-subcortical interaction. An electrical discharge restricted to the? cortex is symptomless (Ip, Riviera, and Walker, 1967); both cortex and subcortical structures must become involved before seizures become clinically evident (Crighel, 1968). When cortical spike activity persists in the cat after convulsions are suppressed by intravenous phenytoin, the drug apparently exerts its effects on subcortical structures (Louis, Kutt, and McDowell, 1968). The sum of the evidence would appear to be that the significant action of the drugs effective in controlling status epilepticus is the restriction of the spread of the seizure discharge in the centrencephalic system.

\section{SUMMARY}

The changes in the EEG of 17 patients during convulsive status treated with intravenous diazepam are reported. The effect of diazepam resembles that of the rapidly acting barbiturates and includes the appearance of burst suppression.

The anticonvulsant action of diazepam appears to be unlike the normal inhibitory process of 'extinction' that arrests a convulsion. When given during a 
secondarily generalized convulsion it reversed the spread of the seizure, suggesting that the restriction or impairment of the spread of the discharge is its main anticonvulsant action. The persistence of the seizure discharge after the arrest of the convulsion indicates that the drug probably exerts its principal anticonvulsant or neuronal depressant effect on subcortical structures and that the underlying epileptogenic process may be relatively unaffected by diazepam and continue to follow its own time course.

I am indebted to Sister D. Walker for her patience, skill, and enthusiasm in the difficult task of producing these recordings. Dr. A. K. Lethlean and Mr. R. S. Gye kindly gave permission to include in this report patients under their care. Roche Products kindly donated Valium used in this project.

\section{REFERENCES}

Bamberger, P., and Matthes, A. (1966). Eine neue Therapiemöglichkeit des Status epilepticus im Kindesalter mit Valium i.v. $Z$. Kinderheilk., 95, 155-163.

Bell, D. S. (1969). Dangers of treatment of status epilepticus with diazepam. Brit. med.J., 1, 159-161.

Bell, D. S., and Kiloh, L. G. (1970). The EEG of status epilepticus. (Submitted for publication.)

Crighel, E. (1968). Experimental data on the mechanism facilitating the passage of interictal spiking foci into focal and generalized seizures. Epilepsia (Amst.), 9, 55-70.

Delamonica, E. A. (1968). Suppression-burst activity. Dis. nerv. Syst., 29, 195-197.

Ellington, A. L. (1968). Electroencephalographic pattern of burst suppression in a case of barbiturate coma. Electroenceph. clin. Neurophysiol., 25, 491-493.

Fenton, G. W., Hill, D., and Scotton, L. (1968). An EEG measure of the effect of mood change on the thiopentone tolerance of depressed patients. Brit. J. Psychiat., 114, 1141-1147.

Gastaut, H., Naquet, R., Poiré, R., and Tassinari, C. A. (1965). Treatment of status epilepticus with diazepam (Valium). Epilepsia (Amst.), 6, 167-182.
Gastaut, H., Poiré, R., Roger, J., and Lob, H. (1967). Les états de mal généralisés tonico-cloniques. In Les Etats de Mal Épileptiques. Pp. 11-43. Edited by H. Gastaut, J. Roger and H. Lob. Masson et Cie: Paris.

_-, Roger, J., Lob, H., and Poiré, R. (1967). Les états de mal généralisés toniques. In Les États de Mal Épileptiques. Pp. 44-76. Edited by H. Gastaut, J. Roger and H. Lob. Masson et Cie: Paris.

,-- , Soulayrol, R., Lob, H., and Tassinari, C. A. (1965). L'action du diazepam (Valium) dans le traitement des formes non convulsives de l'épilepsie généralisée (absences et états d'absence de types divers). Rev. neurol., 112,99-118.

Guerrero-Figueroa, R., Rye, M. M., and Guerrero-Figueroa, C. (1968). Effects of diazepam on secondary subcortical epileptogenic tissues. Curr. therm. Res., 10,150-166.

Henıy, C. E., and Scoville, W. B. (1952). Suppression-burst activity from isolated cerebral cortex in man. Electroenceph. clin. Neurophysiol., 4, 1-22.

Ip, E., Riviera, J., and Walker, A. E. (1967). The propagation of focal cortical seizures in the monkey. J. nerv. ment. Dis., 144, 358-373.

Jaffe, R., and Christoff, N. J. (1967). Intravenous diazepam in seizure disorders. Electroenceph. clin. Neurophysiol., 23,96.

Lombroso, C. T. (1966). Treatment of status epilepticus with diazepam Neurology (Minneap.), 16, 629-634.

Louis, S., Kutt, H., and McDowell, F. (1968). Intravenous diphenylhydantoin in experimental seizures. II. Effect on penicillininduced seizures in the cat. Arch. Neurol. (Chic.), 18, 472-477.

Morrell, F. (1960). Secondary epileptogenic lesions. Epilepsia (Amst.), 1, 538-560.

Nicol, C. F., Tutton, J. C., and Smith, B. H. (1969). Parenteral diazepam in status epilepticus. Neurology (Minneap.), 19, 332-343.

Piqué, E. R., and Henking, R. (1965). Expérimentation clinique et électroencéphalographique du diazepam intraveineux chez les malades épileptiques. Psychiat. et Neurol. (Basel),150,214229.

Prensky, A. L., Raff, M. C., Moore, M. J., and Schwab, R. S. (1967). Intravenous diazepam in the treatment of prolonged seizure activity. New Engl.J. Med., 276, 779-784.

Revol, M., Courjon, J., Gerin, P., and Fischer, G. (1965). Utilisation en pratique électroencéphalographique d'un anticonvulsivant injectable à action rapide (diazépam). Rev. neurol., 113, 266-267.

Wallis, W., Kutt, H., and McDowell, F. (1968). Intravenous diphenylhydantoin in treatment of acute repetitive seizures. Neurology (Minneap.), 18, 513-525. 